$\begin{array}{rr}\text { FURNAL } & \text { Volume } 14, \text { Nomor 3, Mei } 2018 \\ \text { FITOLOGI } & \text { Halaman } 104-109 \\ \text { I N DON E S A } & \text { DOI: } 10.14692 / \text { jfi. } 14.3 .104 \\ \text { ISSN: } 0215-7950 & \end{array}$

KOMUNIKASI SINGKAT

\title{
Potensi Metabolit Sekunder Asal Bakteri Endofit dalam Menekan Pertumbuhan Miselium Ganoderma boninense
}

\author{
Potency of Endophytic Bacterial Secondary Metabolite to Inhibit \\ Mycelium Growth of Ganoderma boninense
}

\author{
Fitri Widiantini*, Ceppy Nasahi, Endah Yulia, Serly Noviyawati \\ Universitas Padjadjaran, Jatinangor 45363
}

\begin{abstract}
ABSTRAK
Bakteri endofit merupakan bakteri yang mempunyai hubungan sangat erat dengan tanaman inangnya. Bakteri ini hidup dalam jaringan tanaman tanpa menimbulkan gejala penyakit pada tanaman. Bakteri endofit dikenal sebagai penghasil senyawa-senyawa yang dapat dimanfaatkan dalam perlindungan tanaman. Penelitian ini bertujuan mendeteksi kemampuan bakteri endofit dalam menghasilkan senyawa anticendawan yang dapat menekan perkembangan patogen penyebab penyakit busuk pangkal batang (BPB) yang disebabkan oleh Ganoderma boninense pada tanaman kelapa sawit. Bakteri endofit yang sebelumnya menunjukkan aktivitas anticendawan secara in vitro ditumbuhkan dalam medium international streptomyces project 2 (ISP2) cair dan diinkubasikan pada alat kocok putar dengan kecepatan 120 rpm selama 10 hari. Filtrat yang telah dipisahkan dari sel-sel bakteri diuji kemampuannya dalam menghambat pertumbuhan $G$. boninense menggunakan well diffusion agar method. Senyawa yang dihasilkan oleh bakteri endofit BEK6, BEK7, BEK9 dan BEK10 dapat menghambat pertumbuhan G. boninense. Secara mikroskopi tampak malformasi pada miselium $G$. boninense yang diperlakukan dengan filtrat bakteri endofit.
\end{abstract}

Kata kunci: filtrat bakteri endofit, kelapa sawit, malformasi miselium, penyakit busuk pangkal batang, senyawa anticendawan

\begin{abstract}
Endophytic bacteria have a close relationship with their host plants. The bacteria are living inside their host without causing any symptom. Endophytic bacteria are well known for their ability to produce compounds that can be used to protect plants from deleterious microorganisms. The research was conducted to determine the ability of endophytic bacteria in producing antifungal compounds that are able to suppress the growth of Ganoderma boninense, a causal agent of basal stem rot disease of oil palm. Previously isolated endophytic bacteria were grown on international streptomyces project 2 (ISP2) liquid medium and incubated at rotary evaporator at $120 \mathrm{rpm}$ for 10 days. The supernatant was separated from bacterial cells and tested against $G$. boninense using well diffusion agar method. The results showed that endophytic bacteria isolate of BEK6, BEK7, BEK9 and BEK10 were able to produce antifungal compound against $G$. boninense. Microscopic observation demonstrated G. boninense mycelia alteration following secondary metabolite application.
\end{abstract}

Key words: antifungal compound, basal stem rot disease, endophytic bacteria filtrate, mycelia alteration, oil palm

\footnotetext{
*Alamat penulis korespondensi: Departemen Hama dan Penyakit Tumbuhan, Fakultas Pertanian, Universitas Padjadjaran. Jalan Raya Bandung-Sumedang KM 21, Jatinangor 45363.

Tel: +6222 7796316, Faks: +6222 7796316, Surel: fitri.widiantini@unpad.ac.id
} 
Ganoderma boninense merupakan patogen yang menimbulkan kerugian besar pada pertanaman kelapa sawit. Patogen ini menyebabkan penyakit busuk pangkal batang (BPB) yang dapat menyebabkan kematian pada tanaman. Umumnya penyakit BPB dikendalikan dengan metode kultur teknis, secara biologi menggunakan Trichoderma atau fungisida sintetik. Akan tetapi, hingga saat ini tidak ada satu jenis metode pengendalian yang efektif untuk mengendalikan penyakit BPB. Fungisida yang masih menjadi andalan untuk mengendalikan penyakit BPB umumnya hanya bersifat menghambat sementara saja dan tidak menyebabkan kematian $G$. boninense. Oleh karena itu, pencarian senyawa yang dapat mengendalikan penyakit BPB harus terus dilakukan.

Bakteri merupakan salah satu mikroorganisme yang dapat berperan sebagai sumber biofungisida. Biofungisida merupakan populasi mikoorganisme atau senyawa yang dihasilkannya yang dapat menghambat atau menghancurkan patogen tanaman. Sebanyak 20000 jenis senyawa aktif dihasilkan oleh mikrob (Brader et al. 2014) dan 3800 jenis di antaranya diproduksi oleh bakteri (Pathma et al. 2011).

Bakteri endofit hidup di dalam jaringan tanaman tanpa menimbulkan gejala penyakit. Selain dapat memacu pertumbuhan tanaman, bakteri endofit juga berperan sebagai agens pengendali hayati. Setelah memasuki jaringan tanaman, bakteri endofit akan mengolonisasi inang sehingga dapat menghambat pertumbuhan patogen melalui kompetisi ruang dan nutrisi. Bakteri endofit juga dapat melindungi tanaman dari infeksi patogen dengan mengeluarkan senyawa metabolit sekunder yang merupakan senyawa bioaktif yang dapat mematikan patogen.

Nasahi et al. (2016) berhasil mengisolasi bakteri endofit dari akar tanaman kelapa sawit yang menunjukkan kemampuan dalam menekan pertumbuhan $G$. boninense. Disebutkan bahwa bakteri endofit tersebut mampu menekan pertumbuhan patogen dengan kisaran antara $8.13 \%$ hingga $49.38 \%$. Secara mikroskopi, miselium G. boninense mengalami penipisan dan hancur menjadi potongan kecil-kecil. Diduga bakteri-bakteri tersebut mengeluarkan senyawa yang bersifat antibiosis terhadap $G$. boninense. Oleh karena itu, penelitian ini bertujuan mendeteksi potensi senyawa metabolit sekunder yang dihasilkan oleh bakteri endofit asal kelapa sawit dalam menghambat pertumbuhan $G$. boninense.

Deteksi potensi senyawa metabolit sekunder bakteri endofit dilakukan dengan menumbuhkan sebanyak 2 koloni tunggal setiap bakteri endofit yang diisolasi dari akar tanaman kelapa sawit sehat (BEK5, BEK6, BEK 7, BEK8, BEK9, BEK10 dan BEK11) dalam $100 \mathrm{~mL}$ medium ISP 2 cair $(4 \mathrm{~g}$ yeast extract, $10 \mathrm{~g}$ malt extract, dan 4 g glukosa dilarutkan dalam $1 \mathrm{~L}$ akuades, $\mathrm{pH} 7.2 \pm 0.2$ ). Bakteri tersebut diinkubasikan dalam inkubator berputar dengan kecepatan $120 \mathrm{rpm}$ pada suhu ruang selama 10 hari (Kiranmayi et al. 2011). Perbanyakan dalam medium ISP2 cair dilakukan sebanyak 4 ulangan dan kerapatan sel bakteri diukur menggunakan spetrofotometer. Supernatan dipisahkan dari sel bakteri melalui beberapa tahap melalui sentrifugasi, kemudian dilanjutkan penyaringan dengan kertas Whatman no 1 , dan selanjutnya supernatan dimurnikan menggunakan saringan milipore berdiameter $0.22 \mu \mathrm{m}$. Filtrat yang diduga mengandung senyawa metabolit sekunder selanjutnya digunakan untuk uji aktivitas anticendawan, yakni terhadap $G$. boninense (Mardanova et al. 2017).

Aktivitas anticendawan senyawa metabolit sekunder yang dihasilkan oleh bakteri endofit dilakukan dengan metode well diffusion agar (Balouiri et al. 2016). Sebanyak $30 \mu \mathrm{L}$ filtrat dari masing-masing isolat bakteri dimasukkan ke dalam sumur kedalaman $5 \mathrm{~mm}$ dan diameter $6 \mathrm{~mm}$ pada medium agar-agar dekstrosa kentang (ADK) dalam cawan petri. Selanjutnya potongan biakan $G$. boninense berdiameter $6 \mathrm{~mm}$ diletakkan pada permukaan mediumADK sejauh $3 \mathrm{~cm}$ dari sumur yang telah diisi filtrat bakteri. Aktivitas penghambatan dihitung dengan mengukur jari-jari koloni dan dibandingkan dengan jari-jari koloni $G$. boninense pada perlakuan kontrol (sumur diisi 
dengan akuades steril). Pengamatan dilakukan pada saat pertumbuhan $G$. boninense pada perlakuan kontrol sudah memenuhi cawan petri (14 hari). Selanjutnya pengaruh senyawa metabolit sekunder terhadap morfologi $G$. boninese diamati dengan mikroskop.

Hasil uji aktivitas antagonisme menunjukkan adanya senyawa yang berpotensi memiliki sifat antagonis terhadap pertumbuhan koloni G. boninense. Sebanyak 7 perlakuan bakteri endofit yang diuji menunjukkan respons yang berbeda terhadap pertumbuhan miselium G. boninense (Tabel 1; Gambar 1). Analisis statistik menunjukkan bahwa kemampuan senyawa metabolit sekunder yang dihasilkan oleh empat isolat bakteri endofit asal akar kelapa sawit (BEK6, BEK7, BEK9 dan BEK10) secara nyata $(\mathrm{P}<0.05)$ dapat menghambat pertumbuhan miselium $G$. boninense dibandingkan dengan perlakuan lainnya. Penghambatan tertinggi ditunjukkan oleh isolat BEK10, yaitu sebesar $36.43 \%$. Perlakuan metabolit sekunder asal bakteri endofit BEK5, BEK8 dan BEK11 yang diuji tidak dapat menghambat pertumbuhan miselium G. boninense (Tabel 1). Senyawa metabolit sekunder yang diaplikasikan pada medium ADK dapat menyebabkan perubahan morfologi pada miselium $G$. boninense (Gambar 2c, d, dan e). Perubahan morfologi yang terlihat antara lain hifa menjadi lebih tipis, melentur dan berputar arah serta mengeriting (BEK6, BEK9, BEK10 dan BEK11). Perlakuan BEK5, BEK7, dan BEK8 tidak menunjukkan perubahan morfologi miselium G. boninense, morfologi miseliumnya relatif sama dengan kontrol (Gambar 2a dan b). Sementara pada perlakuan lainnya terlihat adanya perubahan morfologi miselium $G$. boninense. Senyawa metabolit sekunder yang dihasilkan oleh bakteri endofit pada medium ISP2 diduga bersifat fungistatis. Kemungkinan juga menghasilkan fungisida dalam jumlah sedikit sehingga tidak menimbulkan efek fungisidal.

Simionato et al. (2017) melaporkan bahwa bakteri Pseudomonas aeruginosa LV dapat menghambat pertumbuhan Botrytis cinerea patogen pascapanen pada banyak buah-buahan. Senyawa yang dimiliki batkteri tersebut dapat menyebabkan miselium $B$. cinerea yang tadinya mempunyai permukaan yang halus menjadi kasar dan keriting. Senyawa metabolit sekunder yang dikeluarkan oleh $B$. subtilis dilaporkan menyebabkan terjadinya perubahan morfologi miselium pada Fusarium sp. dan Alternaria alternata sehingga pertumbuhan patogen tersebut menjadi terhambat (Mardanova et al. 2017). Wibowo et al. (2017) juga melaporkan bahwa bakteri yang diisolasi dari perakaran tanaman kelapa sawit dapat menghasilkan senyawa kitinolitik yang dapat menghambat pertumbuhan $G$. boninense.

Produksi senyawa metabolit sekunder yang dihasilkan oleh bakteri dipengaruhi oleh kandungan nutrisi medium tumbuhnya. Pseudoncardia VUK-10 dapat menghasilkan senyawa metabolit bioaktif yang tinggi

Tabel 1 Penghambatan miselium Ganoderma boninense pada medium agar-agar dekstrosa kentang yang diberi perlakuan senyawa metabolit sekunder dari bakteri endofit asal akar tanaman kelapa sawit pada 14 hari setelah inokulasi

\begin{tabular}{lcc}
\hline $\begin{array}{l}\text { Isolat asal metabolit } \\
\text { sekunder }\end{array}$ & $\begin{array}{c}\text { Jari-jari miselium } \\
\text { G. boninense }(\mathrm{cm}) *\end{array}$ & $\begin{array}{c}\text { Penghambatan pertumbuhan } \\
\text { miselium }\end{array}$ \\
\hline Kontrol boninense (\%)
\end{tabular}




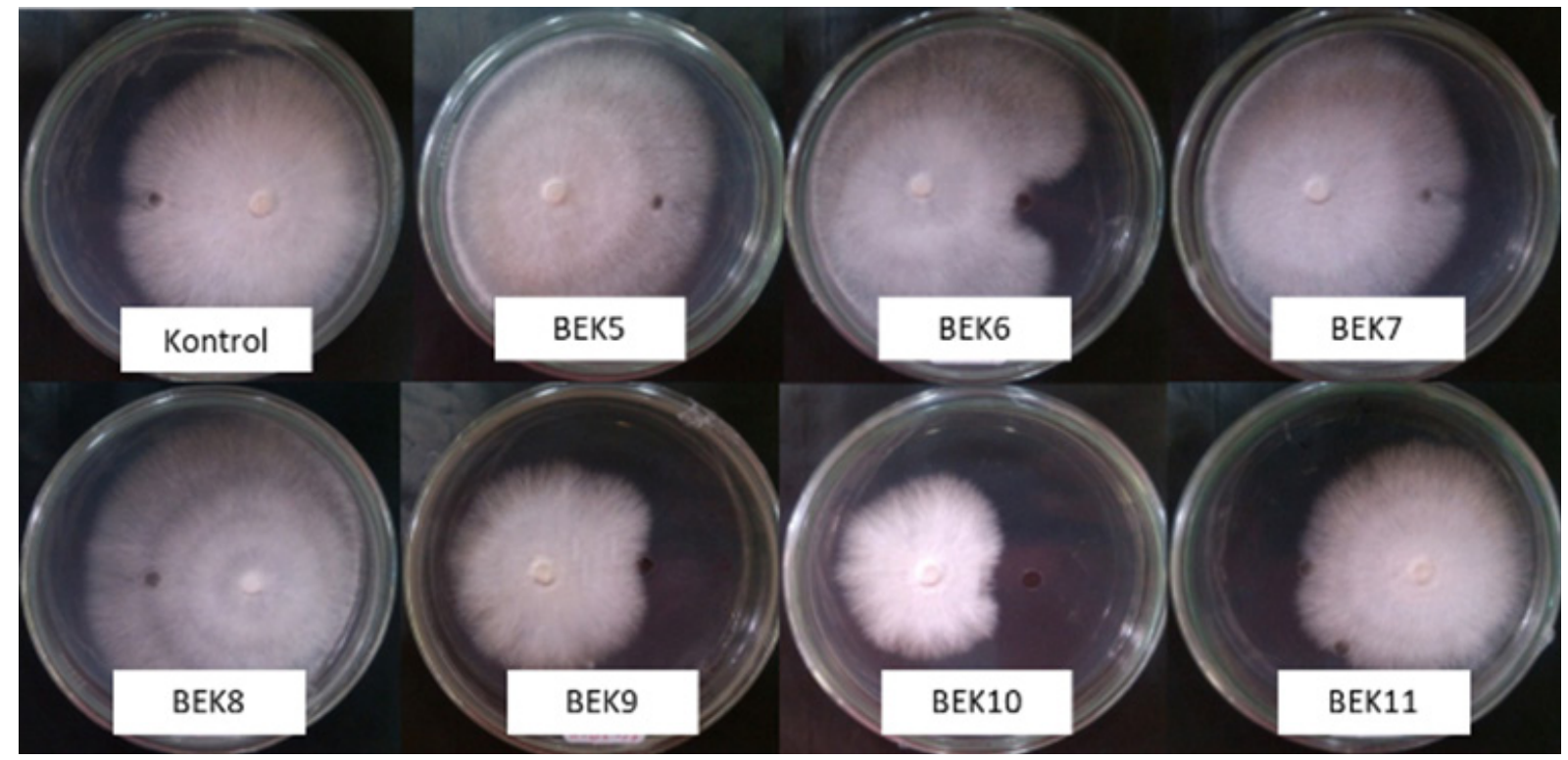

Gambar 1 Pengaruh senyawa metabolit sekunder yang diekstraksi dari bakteri endofit akar kelapa sawit terhadap miselium $G$. boninense (BEK5-BEK11) dan ditumbuhkan pada medium cair ISP2 dalam menghambat pertumbuhan miselium $G$. boninense menggunakan metode well diffusion agar pada medium agar-agar dekstrosa kentang. Pada perlakuan kontrol, akuades steril digunakan sebagai pengganti filtrat.

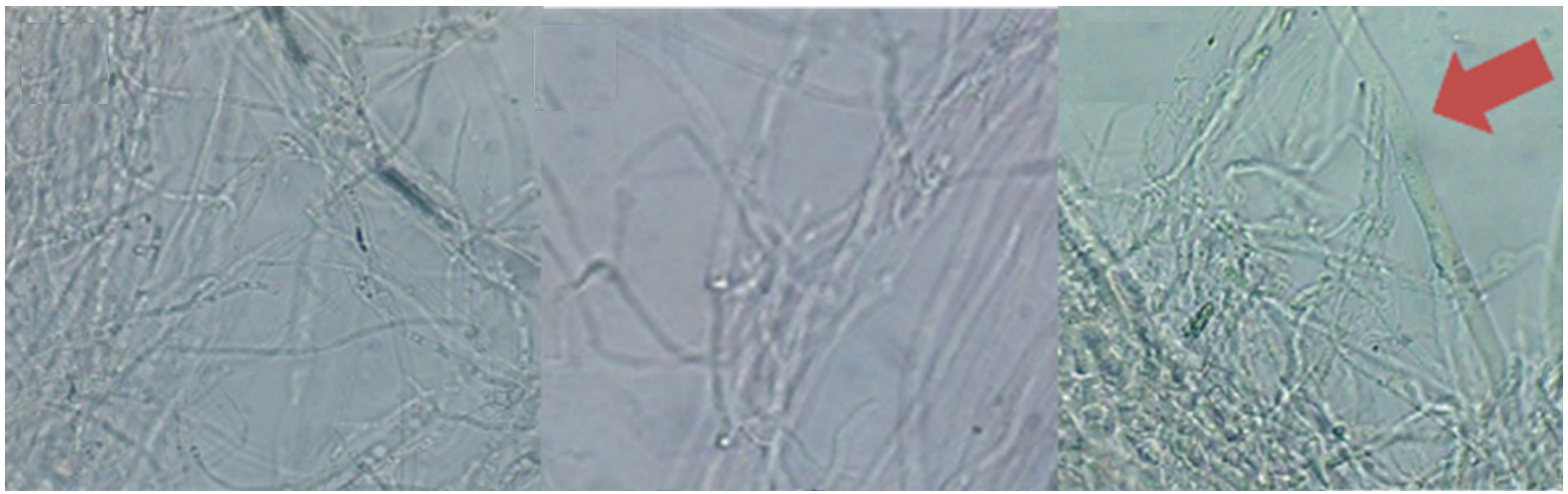

a

b

$\mathrm{C}$

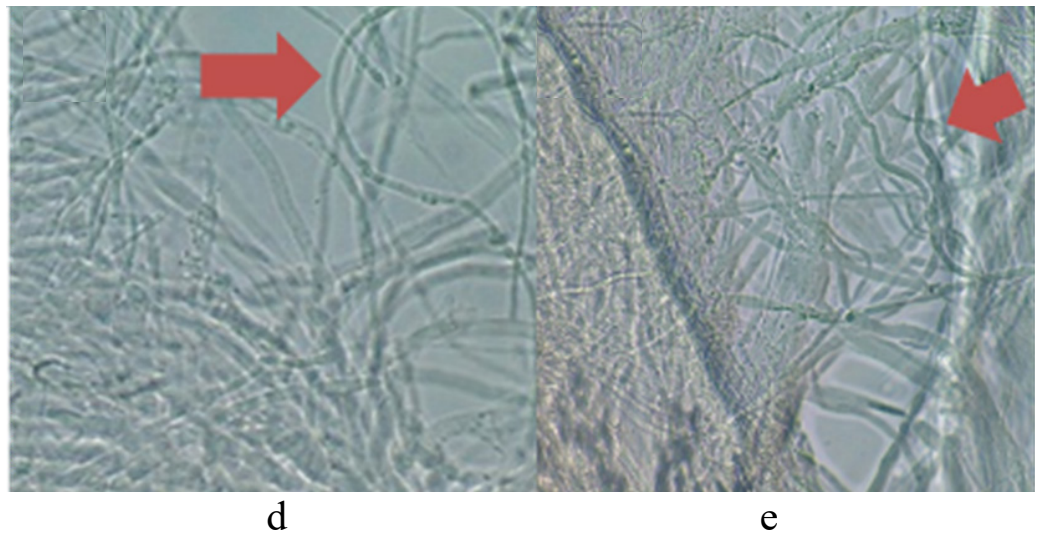

Gambar 2 Pengaruh senyawa metabolit sekunder asal bakteri endofit kelapa sawit terhadap morfologi miselium G. boninense pada perbesaran 400× . a, Hifa normal (kontrol); b, hifa tidak mengalami perubahan (BEK5, BEK7, BEK8); c, hifa yang mengalami penipisan (BEK6 dan BEK10); d, hifa mengalami penipisan dan pelenturan (BEK9); e, hifa mengalami pelebaran dan keriting (BEK11). 
pada medium ISP2 (Kiranmayi et al. 2011). Streptomyces sp. PM49 dilaporkan menghasilkan senyawa metabolit sekunder $\beta$-lactam saat ditumbuhkan pada medium ISP2 (Shanthi et al. 2015).

Kemampuan bakteri dalam menghasilkan senyawa metabolit sekunder yang bersifat antagonis dipengaruhi juga oleh kemampuannya berkomunikasi dengan bakteri lain, yang disebut sebagai quorum sensing (QS) (Hadiwiyono 2009). Senyawa metabolit sekunder dihasilkan oleh bakteri melalui gen yang ekspresinya bergantung pada kepadatan sel. Ketika jumlah populasi memenuhi quorum, sel-sel bakteri tersebut akan berkomunikasi satu dengan yang lainnya dan mengubah perilakunya sesuai dengan kondisi lingkungan. Perilaku yang dihasilkan dapat berupa produksi senyawa metabolit sekunder, perubahan fenotipe, atau pembentukan biofilm (Chin-A-Woeng et al. 2003; Hadiwiyono 2009).

Melihat potensinya dalam menghambat pertumbuhan koloni dan pengaruhnya terhadap morfologi miselium $G$. boninense, perlu dilakukan upaya untuk memurnikan dan mengoptimalkan produksi senyawa metabolit sekunder yang disekresikan dalam medium cair ISP2 oleh bakteri endofit asal kelapa sawit ini (BEK6, BEK9, BEK10, dan BEK11) sehingga efektifitasnya untuk pengendalian $G$. boninense menjadi lebih baik lagi.

\section{UCAPAN TERIMA KASIH}

Terima kasih disampaikan kepada Universitas Padjadjaran melalui dukungan dana dari Hibah Internal Universitas Padjadjaran (HIU) tahun anggaran 2017 dengan skema Riset Fundamental Universitas Padjadjaran No. 855/UN6.3.1/PL/2017.

\section{DAFTAR PUSTAKA}

Balouiri M, Sadiki M, Ibnsouda SK. 2016. Methodsforinvitroevaluatingantimicrobial activity: A review. J Pharmaceutic Anal. 6(2):71-79. DOI: https://doi.org/10.1016/j. jpha.2015.11.005.
Brader G, Compant S, Mitter B, Trognitz F, Sessitsch A. 2014. Metabolic potential of endophytic bacteria. Curr Opin Biotechnol. 27:30-37. DOI: https://doi.org/10.1016/j. copbio.2013.09.012.

Chin-a-Woeng TFC, Bloemberg GV, Lugtenberg BJJ. 2003. Phenazines and their role in biocontrol by Pseudomonas bacteria. New Phytol. 157(3):503-523. DOI: $\quad$ https://doi.org/10.1046/j.14698137.2003.00686.x.

Hadiwiyono. 2009. Quorum sensing: suatu sistem komunikasi bakteri fitopatogen, peranannya pada proses infeksi, dan peluangnya sebagai basis pengembangan strategi baru dalam pengendalian penyakit tumbuhan. JPTI. 15(2):45-54. DOI: 10.22146/jpti.11765.

Kiranmayi MU, Sudhakar P, Sreenivasulu K, Vijayalakshmi M. 2011. Optimization of culturing conditions for improved production of bioactive metabolites by Pseudonocardia sp. VUK-10. Mycobiology.39(3):174-181.DOI: https:// doi.org/10.5941/MYCO.2011.39.3.174.

Mardanova AM, Hadieva GF, Lutfullin MT, Khilyas IVE, MinnullinaLF, GilyazevaAG, Bogomolnaya LM, Sharipova MR. 2017. Bacillus subtilis strains with antifungal activity against the phytopathogenic fungi. Agr Sci. 8(1):1-20. DOI: https://doi. org/10.4236/as.2017.81001.

Nasahi C, Widiantini F, Yulia E, Meliansyah R, Rasisetyo P. 2016. Isolasi dan deteksi potensi aktinobacteria endofit dalam mengendalikan penyakit busuk pangkal batang pada tanaman kelapa sawit (Ganoderma boninense Pat.). Di Dalam: Joko T, editor. Prosiding Seminar Nasional Pengendalian Penyakit pada Tanaman Ramah Lingkungan II, 2016 Agustus 27. Yogyakarta (ID): Perhimpunan Fitopatologi Indonesia. hlm. 66-78.

Pathma J, Rahul GR, Kennedy RK, Subashri R, Sakthivel N. 2011. Secondary metabolite production by bacterial antagonists. J Biol Control. 25(3):165-181.

Shanthi J, Senthil A, Gopikrishnan V, Balagurunathan R. 2015. Characterization 
of a potential $\beta$-lactamase inhibitory metabolite from a marine Streptomyces $\mathrm{sp}$. PM49 active against multidrug-resistant pathogens. Appl Biochem Biotechnol. 175(8):3696-3708. DOI: https://doi. org/10.1007/s12010-015-1538-x.

Simionato AS, Navarro MOP, De Jesus MLA, Barazetti AR, Da Silva CS, Simões GC, Balbi-Peña MI, De Mello JCP, Panagio LA, De Almeida RSC, Andrade G, De Oliveira AG. 2017. The effect of phenazine-1-carboxylic acid on mycelial growth of Botrytis cinerea produced by Pseudomonas aeruginosa LV strain. Front Microbiol. 8:1102. DOI: https://doi. org/10.3389/fmicb.2017.01102.

Wibowo RH, Mubarik NR, Rusmana I, Thenawidjaya M. 2017. Penapisan dan identifikasi bakteri kitinolitik penghambat pertumbuhan Ganoderma boninense in vitro. J Fitopatol Indones. 13(3):105-111. DOI: https://doi.org/10.14692/jfi.13.3.105. 